\title{
ANSERJ
}

Vol. 11, No. 2

Autumn / Automne 2020

pp. $35-55$

Canadian Journal of Nonprofit and Social Economy Research

Revue canadienne de recherche sur les OBSL et l'économie sociale

\section{When the Means Modify the Ends: (E)Valuating and Transforming the Purpose of a Nonprofit Organization through Impact Assessment}

\author{
Chantale Mailhot \\ HEC Montréal \\ Valérie Michaud \& Sonia Tello-Rozas \\ ESG-UQAM
}

\begin{abstract}
In a context marked by a trend toward marketization and a rise in performance measures, nonprofit organizations (NPOs) are under pressure to show that their activities have visible impacts. Based on the Economies of Worth framework derived from French pragmatist sociology, this article explores how NPOs may come to change what they value and their fundamental purpose. More specifically, it delves into the process of valuation triggered by the intervention of consultants who were retained to help an NPO develop an impact evaluation tool aimed at legitimizing its actions. The findings show how this process led to a complete redefinition of the NPO's "theory of change," ultimately distancing the NPO from its initial, explicit purposes.
\end{abstract}

\section{RÉSUMÉ}

Dans un contexte marqué par une tendance à la marchandisation des activités et une exigence accrue de mesures de performance, les organismes à but non lucratif (OBNL) sont soumises à la pression de démontrer les impacts de leurs activités. À partir du cadre théorique des Économies de la grandeur issu de la sociologie pragmatiste française, cet article explore comment les OBNL peuvent en venir à modifier ce qu'elles valorisent, voire leur mission même. Plus précisément, l'article décortique le processus de « valuation » déclenché par l'intervention de consultants embauchés pour appuyer un OBNL dans le développement d'un outil d'évaluation d'impact visant à légitimer ses actions. Nos résultats montrent comment ce processus a conduit l'OBNL à une redéfinition complète de sa « théorie du changement », l'éloignant finalement de ses objectifs initiaux.

Keywords / Mots clés : Valuation; Impact assessment; Economies of Worth; Nonprofit organization : valuation; évaluation d'impact; économies de la grandeur, organismes à but non lucratif 


\section{Mailhot, Michaud, \& Tello-Rozas (2020)}

\section{INTRODUCTION}

Over the last decades, organizations have faced rising quantification and performance measures to meet the demands for efficiency and accountability (e.g., Chiapello, 2015; Espeland \& Sauder, 2007). Quantitative assessment tools strongly encourage the measurement of outcomes, results, and impacts (Martinus Hauge, 2016), even in areas that have traditionally escaped measure. Nonprofit organizations (NPOs) must now justify their use of resources relying on the evaluation and measure of their activities and impacts, despite the difficulty this poses (Arvidson, 2009; Moxham, 2010). In a context of increased competition for scarce resources (Jäger \& Schröer, 2014), NPOs, implicitly or explicitly, engage in such assessments to demonstrate their contribution, legitimize their activities, and, ultimately, justify their existence (Arvidson \& Lyon, 2014; Grieco, Michelini, \& lasevoli, 2015).

Measuring the impacts of NPOs introduces the difficulty of measuring elements that are not always easily quantifiable (Fourcade, 2011), and raises the question of the possible effects or consequences of such economic evaluations of and on NPOs' social and cultural activities (Chiapello, 2015). Indeed, the mere fact of evaluating is intrinsically related to what is considered to be valuable (Martinus Hauge, 2016) and may also affect the behaviour of the individuals and organizations measured (Espeland \& Sauder, 2007). Such considerations have stimulated the emergence of the field of "valuation studies" (Kornberger, 2017; Martinus Hauge, 2016; Orlikowski \& Scott, 2013), which represents a pragmatist turn in the study of value in social science (Barman, 2015). Valuation studies share a common interest in the practices by which value or "worth" is assigned to persons, objects, or activities (Lamont, 2012), and address "how value is produced, diffused, assessed, and institutionalized across a range of settings" (Lamont, 2012, p. 4). While valuation is the practice of giving value, evaluation is the practice of assessing value (Lamont, 2012). This allows for a novel perspective on the development of impact assessment tools, and on how to understand the construction and negotiation of value by NPOs in order to legitimize themselves.

The central argument of this article is that in the process of trying to grasp their contribution through impact assessment tools, NPOs can rapidly and insidiously lose sight of their central, deeply entrenched vision of what they value. Thus, it is important to uncover the details of the valuation process, which is the aim of this empirical, qualitative study. It analyzes a consultant-led process of setting up impact assessment tools in an NPO through the lens of French pragmatist sociology's Economies of Worth (EW) (Boltanski \& Thévenot, 2006). A "sociological theory of value" (Stark, 2009, p. 10), Boltanski and Thévenot's (2006) Economies of Worth framework offers a relevant analytical grid to unveil how organizations justify and legitimize their actions with stakeholders, as well as the value they grant to their activities. It "shows in rich detail how the principles of evaluation established in each order of worth entail discrete conceptions of what is considered 'good' through different metrics, measuring 'instruments,' and proofs of worth objectified in artifacts and objects in the material world," (Stark, 2009, p. 13) As such, this framework enables a link between evaluation and legitimization through a repertoire of evaluation criteria.

This article draws from the Economies of Worth framework to answer the following question: How can the establishment of evaluation tools transform the purpose that an organization puts forward when justifying its activities? Through a longitudinal study of Enacting, a NPO specialized in theatre-intervention (i.e. an emancipatory approach aimed at giving a voice and dramatize the experiences of "ordinary people" through drama experiments), this study identifies three elements that allow for the rapid change of what is of value and, ultimately, of the very purpose of a nonprofit. The first is related to the combination of different "worlds" (in Boltanski and Thévenot's terms, as will soon be explained in the conceptual framework) in which the consultant firm's intervention is initially positioned, allowing consultants to exercise authority in their role of facilitator. The second element is the deductive approach adopted by the consultants leading the process. The last important element resides in the particularity of the tools used to frame the process and collect the data. As will be argued below, previous research has documented different evaluation tools for NPOs and the reasons why NPOs de- 


\section{Mailhot, Michaud, \& Tello-Rozas (2020)}

velop them. Research addressing the ways establishing these tools can impact NPOs, and the actual processes through which NPOs come to transform themselves and what they value along the way, however, is scarce. This is specifically what this article aims to uncover, thus bringing an original "valuation" lens to the understanding of the impact assessment issues facing NPOs.

This article begins with a review of the literature on the evaluation of NPOs, valuation, and the Economies of Worth framework that provide the conceptual ground for the empirical study. Research methods, findings, a discussion, and a conclusion follow.

\section{CONCEPTUAL BACKGROUND}

\section{Nonprofit organizations' performance and impact evaluation}

The performance and impact evaluation of NPOs has been extensively explored. Several authors have reviewed the literature on the topic (e.g., Forbes, 1998; Lecy, Schmitz, \& Swedlund, 2012; Micheli \& Kennerley, 2005; Ruebottom, 2011) and various assessment tools and models have been analyzed and proposed (e.g., Dougherty, 2019). This has even been undertaken for very specific sectors (see Alberio \& Tremblay, 2014, for work insertion social enterprises; Lum, Shields, \& Evans, 2016, for non-governmental organizations).

Matthew Hall (2014) points out that to understand the evaluation tools and models used by NPOs, it is necessary to analyze their inherent logic. In analyzing the evaluation tools most frequently used by NPOs, Hall (2014) proposes a typology based on three logics of evaluation: 1) the learning evaluation logic, characterized by the richness of data from as many actors as possible, a focus on telling stories or events, and an evaluator acting as a facilitator helping organizations to focus their evaluation; 2) the scientific logic, characterized by "a strong focus on systematic observation, gathering of observable and measurable evidence" (Hall, 2014, p. 321), in which the data collection process is not influenced by personal feelings and the evaluator assumes a role of scientist, possessing the technical knowledge necessary for the implementation of a specific evaluation tool; 3) the bureaucratic logic, which seeks a certain categorization of results and impacts mobilizing models such as the theory of change model or a logic model, in which the evaluator acts as an evaluation tool implementer.

There are multiple reasons explaining the increasingly frequent use of performance and impact assessments by NPOs. Taking stock of the extensive literature on the subject, two major motives can be highlighted. For an NPO, evaluation is a means of accountability (Eynaud \& Mourey, 2012; Glassman \& Spahn, 2012; Greatbanks \& Manville, 2010; Greiling \& Stötzer, 2015) and a way to legitimize and inform stakeholders about the results of its activities (e.g., Arvidson \& Lyon, 2014; Eckerd \& Moulton, 2010; Luke, Barraket, \& Eversole, 2013; Maier, Schober, Simsa, \& Millner, 2015; Manetti, 2014; Millar \& Hall, 2013; Yu \& McLaughlin, 2013).

Yet despite numerous writings on the subject of NPO evaluation, the lack of theorizing is still a call for researchers in this field (Hall, 2014). Further, notwithstanding many classifications and explorations of the motives that entice NPOs to carry out performance and impact evaluations, the extant literature has not conducted empirical studies that consider "toolsin-use" (Jarzabkowski \& Kaplan, 2015, 538), focusing on the interactions between people and tools and paying attention to the performative effects of these interactions on actors, tools, and organizations, especially in terms of changes in the valuation of activities.

\section{Valuation and the Economies of Worth}

A central background issue with regards to performance and the impact evaluation of NPOs is determining what is valuable and how to justify it, measure it, and produce proof. By choosing (or being strongly encouraged to choose) some 


\section{Mailhot, Michaud, \& Tello-Rozas (2020)}

performance indicators over others in the design of their evaluation tools, NPOs signal the importance and value they grant to some dimensions of their actions over others. As such, evaluation is intrinsically and implicitly linked to valuation. Yet, rarely have scholars studied evaluation in NPOs from a valuation lens.

Recently developed, the concept of "valuation" refers to the social practices that aim to give value to any entity, whether it is a person, an action, an object, or an event (Lamont, 2012). Inspired by John Dewey's (1939) pragmatist theory of valuation, the concept of valuation draws attention to the fact that value is the result of a practical activity and not an intrinsic characteristic of an object. Valuation can be defined as "any social practice where the value or values of something is established, assessed, negotiated, provoked, maintained, constructed and/or contested" (Doganova, Giraudeau, Helgesson, Kjellberg, Lee, Mallard, Mennicken, Muniesa, Sjögren, \& Zuiderent-Jerak, 2014, p. 87). As Martin Kornberger (2017) writes, a "focus on valuation practices ... disentangles the concept of value in order to understand the concrete practices and processes through which something is constituted as valuable in the first place" (p. 6).

Valuation studies typically focus on the effects of valuation devices, mainly tools of evaluation and quantitative assessment, on the activity they monitor (Espeland \& Sauder, 2007; Martinus Hauge, 2016). For instance, Wendy Nelson Espeland and Michael Sauder (2007) investigated the consequences of a public measure of ranking on a law school and showed how it affected the university management itself. Such research shows that the act of measurement is not neutral and can have significant effects on the cognition and action of people in organizations. It highlights how the act of measuring not only determines the value of the object, person, or action being measured, but also what is considered to be of value in organizational settings (Martinus Hauge, 2016; Reinecke, 2010).

Scholars have uncovered the multiplicity of valuation registers (Heuts \& Mol, 2013), valuation modes (Martinus Hauge, 2016), or evaluation principles (Chenhall, Hall, \& Smith, 2013). They have argued that financialized valuations increasingly colonize social or cultural activities and environmental issues (Chiapello, 2015), and that people can also translate different conceptions of worth applying to nature into monetary valuation (Fourcade, 2011). Considering organizations as spaces filled with multiple values and ideas about what is valuable, Amalie Martinus Hauge (2016) investigated how the introduction of a valuation device intersects with an organization's working values and demonstrated that a new valuation device competes with other valuations that, even without being supported by official numeric calculations, are nonetheless present in organizational settings. The current study falls within this last stream of research. It draws from the French pragmatist sociology's Economies of Worth (Boltanski \& Thévenot, 2006) framework as an analytical tool to decipher (e)valuation practices by shedding light on different worlds in which distinct values are deemed important.

Luc Boltanski and Laurent Thévenot's (2006) "Economies of Worth" (EW) framework enables the link between valuation, identifying what is good, and evaluation, justification and proof (De Munck \& Zimmermann, 2015). It is based on both Boltanski and Thévenot's own research on the different ways people justify their opinions and actions or critiques in the context of disputes, as well as on their analysis of classic economic, political, and philosophical works (such of those of Adam Smith, Thomas Hobbes, and Jean-Jacques Rousseau). Boltanski and Thévenot (2006) put forward a justification grammar composed of six "worlds." These worlds "refer to the "higher common principles' that reflect the degree of legitimacy of certain rules and values in society and define appropriate forms of conduct" (Patriotta, Gond, \& Schultz, 2011, p. 2). They provide a repertoire of evaluative criteria likely to be drawn on reflexively by competent actors to legitimize their activity (Cloutier, Gond, \& Leca, 2017; Mailhot \& Langley, 2017).

As shown in Table 1, a "common superior principle," a "common good," is identified for each world. Each is further categorized into what is considered to be good and worthy; the associated repertoire of legitimate actors, actions, and tools; and typical tests, proofs, and ways of expressing judgment. These tests and proofs make it possible to evaluate worth 
based on a given world. For instance, the superior principle within the civic world is collective action. As such, justifications from that world value collective welfare, rights, elected representatives, and the common interest, as opposed to the competition and self-interest promoted in the market world. ${ }^{1}$

Table 1: Adapted presentation of Boltanski and Thévenot's (2006) worlds

\begin{tabular}{|c|c|c|c|c|c|c|}
\hline World & Inspired & Civic & Domestic & Fame & Market & Industrial \\
\hline $\begin{array}{l}\text { Common superior } \\
\text { principle }\end{array}$ & Inspiration & Collective action & $\begin{array}{l}\text { Tradition, } \\
\text { hierarchy }\end{array}$ & Opinion & Competition & $\begin{array}{l}\text { Efficiency, } \\
\text { performance }\end{array}$ \\
\hline $\begin{array}{l}\text { What is great and } \\
\text { worthy }\end{array}$ & $\begin{array}{l}\text { The bizarre, } \\
\text { spontaneous, } \\
\text { surprising }\end{array}$ & $\begin{array}{l}\text { The regulatory, } \\
\text { representative, } \\
\text { legal, free }\end{array}$ & $\begin{array}{l}\text { The caring, } \\
\text { well-raised, wise }\end{array}$ & $\begin{array}{l}\text { The famous, } \\
\text { recognized, } \\
\text { visible, convincing }\end{array}$ & $\begin{array}{l}\text { The desirable, } \\
\text { valuable, sellable }\end{array}$ & $\begin{array}{l}\text { The performing, } \\
\text { functional, } \\
\text { trustworthy }\end{array}$ \\
\hline Subjects & $\begin{array}{l}\text { Artist, spirit, } \\
\text { shadow, crazy }\end{array}$ & $\begin{array}{l}\text { Collective } \\
\text { organizations and } \\
\text { their } \\
\text { representatives }\end{array}$ & $\begin{array}{l}\text { Boss, king, father, } \\
\text { chief, } \\
\text { subordinates }\end{array}$ & $\begin{array}{l}\text { Stars, supporters, } \\
\text { spokespeople }\end{array}$ & $\begin{array}{l}\text { Competitors, } \\
\text { sales } \\
\text { representatives, } \\
\text { clients, customers }\end{array}$ & $\begin{array}{l}\text { Professionals, } \\
\text { experts, } \\
\text { specialists }\end{array}$ \\
\hline $\begin{array}{l}\text { Tools and } \\
\text { dispositifs }\end{array}$ & $\begin{array}{l}\text { Spirit, body, } \\
\text { dream, } \\
\text { unconscious }\end{array}$ & $\begin{array}{l}\text { Legal forms, } \\
\text { rights, bylaws, } \\
\text { codes }\end{array}$ & $\begin{array}{l}\text { Good manners, } \\
\text { titles }\end{array}$ & $\begin{array}{l}\text { Media, brand, } \\
\text { message, } \\
\text { campaign }\end{array}$ & $\begin{array}{l}\text { Money, luxury } \\
\text { objects }\end{array}$ & $\begin{array}{l}\text { Means, tools, } \\
\text { resources, } \\
\text { methods }\end{array}$ \\
\hline Actions & $\begin{array}{l}\text { Creating, } \\
\text { discovering, } \\
\text { imagining, } \\
\text { dreaming }\end{array}$ & $\begin{array}{l}\text { Rallying, } \\
\text { mobilizing, } \\
\text { unifying }\end{array}$ & $\begin{array}{l}\text { Reproducing, } \\
\text { educating, inviting }\end{array}$ & $\begin{array}{l}\text { Persuading, } \\
\text { influencing, } \\
\text { convincing }\end{array}$ & $\begin{array}{l}\text { Catching one's } \\
\text { interest, buying, } \\
\text { selling }\end{array}$ & $\begin{array}{l}\text { Getting to work, } \\
\text { implementing }\end{array}$ \\
\hline Test & Adventure, quest & $\begin{array}{l}\text { Cause-related } \\
\text { demonstration, } \\
\text { assembly, } \\
\text { congress }\end{array}$ & $\begin{array}{l}\text { Family, } \\
\text { ceremonial }\end{array}$ & $\begin{array}{l}\text { Conference, } \\
\text { event, } \\
\text { demonstration }\end{array}$ & Deal signed & Test, start-up \\
\hline $\begin{array}{l}\text { Mode of } \\
\text { expressing } \\
\text { judgement }\end{array}$ & $\begin{array}{l}\text { Stroke of genius, } \\
\text { illumination }\end{array}$ & $\begin{array}{l}\text { Voting results, } \\
\text { election, } \\
\text { mobilization }\end{array}$ & Trustworthiness & $\begin{array}{l}\text { Mass opinion, } \\
\text { rumor }\end{array}$ & Price, value & $\begin{array}{l}\text { Efficiency, } \\
\text { working }\end{array}$ \\
\hline Proof & Intuition & $\begin{array}{l}\text { Rules, laws, } \\
\text { bylaws }\end{array}$ & $\begin{array}{l}\text { Anecdote, } \\
\text { example }\end{array}$ & Success & $\begin{array}{l}\text { Money, profit, } \\
\text { results }\end{array}$ & Measure \\
\hline
\end{tabular}

As put by Gerardo Patriotta, Jean-Pascal Gond, and Friederike Schultz (2011) — who used EW to study the maintenance of legitimacy in the context of a controversy, namely a nuclear accident—worlds or "orders of worth are legitimate forms of common good, which provide universal principles logical coherence as well as justice" (p. 1809). Through the concept of justification based on the principles encapsulated in these worlds, the EW framework thus makes it possible to capture how actors can try to challenge one's legitimacy, but it also outlines how legitimacy can be maintained.

In line with recent contributions of Charlotte Cloutier, Jean-Pascal Gond, and Bernard Leca (2017) and Jon Bertilsson and Jens Rennstam (2017), this study approaches EW as a relevant and rich analytical framework that makes it possible to grasp the multiple principles at play in the study of valuation practices leading to evaluation. Indeed, a stream of research is currently emerging, with empirical studies of these practices starting to use the EW framework and its repertoire of evaluative criteria drawn on by actors to justify their activities. Among them, Chantale Mailhot and Ann Langley (2017), building on Boltanski and Thévenot (2006), conceptualize academic knowledge commercialization as a process of "valuation" in which different values are assigned to knowledge as it travels from university to practice. They show that in the 


\section{Mailhot, Michaud, \& Tello-Rozas (2020)}

presence of multiple orders of worth, actors must build synergistic assemblages. Juliane Reinecke's (2010) study of the complex price-setting process by organizations that utilize fair-trade labelling also depicts how the EW framework can contribute to the deciphering of valuation practices that involve multiple worlds that "reflect political and moral assumptions of how worth can be attributed to particular things if an order is to be recognized as legitimate" (p. 565). Robert Chenhall, Matthew Hall, and David Smith (2013) draw on EW and David Stark's (2009) concept of "organizing dissonance" (the idea that the meeting of several evaluation principles can generate a productive debate rather than a conflict) to show the role of design and the operation of accounting practices in facilitating compromise between multiple evaluation principles. For their part, Marcia Annisette, Gillain Vesty, and Thierry Amslem (2017) show how accounting tools, conceived as valuation and compromise devices, can capture multiple worlds in a nonprofit welfare organization and a public-owned water utility. Their work clearly demonstrates the relevance of EW in adopting a valuation lens to study the development of evaluation tools in NPOs.

Indeed, this study uses the EW framework to explore what is considered valuable within the rich context of setting up an impact assessment evaluation tool in an NPO in the cultural sector. This allows for an EW exploration of a valuation processes in an NPO that ultimately changes the organization's "core" worlds and purpose.

\section{METHODS}

This study examines a "strategic clarification process" conducted by a consulting organization, "ConsultingCo" (pseudonym), offering "practical tools for social innovation."2 The intervention was carried out with "Enacting" (pseudonym), an NPO that specialized in theatre-intervention. As put by ConsultingCo, the objective of the strategic clarification exercise was to help Enacting "take decisions in order to maximize their impact while helping others to better understand what motivates the choices." This process, which lasted six months, aimed at helping Enacting clarify what it wanted to do, how to do it, and how to measure success through the establishment of impact measurement tools, with the ultimate goal of giving Enacting stronger legitimacy to access much-needed additional resources.

\section{The case setting and research}

To understand the process through which the consultant-led introduction of impact assessment tools (initially aimed at legitimizing Enacting's actions) transformed Enacting's conceptions of doing good and of the associated value ascribed to it, it is important to have some context about both Enacting and the consulting firm.

Founded in 1991 in Québec (Canada), Enacting was a participatory theatre-intervention team with the mission to mobilize knowledge, solidarity, and citizen power to create a more just and equal world. Enacting was a nonprofit organization governed by a board of directors comprised of eight members. For the studied period (2014-2015), it employed five regular employees and many contractual artists for various projects aiming, for example, at improving relations between police officers and young victims of racial profiling, or between citizens and homeless people. Enacting had been performing forum theatre in the Augusto Boal tradition of "Theatre of the Oppressed" for over 20 years (Boal, 1993). This theatre-intervention approach, developed in Brazilian shantytowns, is based on the idea that everyone has the capacity to act in the theatre of his/her own life. Everybody is at once an actor and a spectator, a spect-actor. The approach of Theatre of the Oppressed contains a repertoire of techniques that seek to mobilize people, establish dialogue, and, most importantly, create space for participants to rehearse taking action.

In 2014, a philanthropic foundation offered Enacting's general manager (a founding member) a bursary allowing him to take a sabbatical year to reflect on Enacting's approach. Since the general manager did not want to be the only team member to engage in a process of reflection that year, he contacted ConsultingCo, which had approached Enacting in the past to offer a strategic "Clarity and Impact" module. In 2014-2015, an Enacting team comprised of three staff members 


\section{Mailhot, Michaud, \& Tello-Rozas (2020)}

(the general manager, then on sabbatical; the administrative manager, who became the interim general manager; and another employee) and two board members (the chairperson and secretary) embarked on ConsultingCo's strategic "Clarity and Impact" module, which, according to its introductory slides, aimed at helping Enacting "examine its actual efforts in a structured, evidence-based way, with regards to the intended impact, how to reach it, how to measure it and to make changes for optimal impact." Financially struggling at that time, Enacting saw the process with ConsultingCo as a potential way to access new resources.

ConsultingCo is a consulting firm launched by a major foundation and an affiliate of a large U.S. strategic consulting firm that specializes in providing social innovation tools to NPOs. ConsultingCo's coaching process with Enacting was divided into the following four steps: 1) an initial workshop, during which two consultants from ConsultingCo (referring themselves as "coaches") presented the analytical framework and the formulation of a first statement of "intended impact and theory of change," which looks for "[i]mprovements over time in knowledge, attitudes, values, skills, behaviours, condition, or status that are measurable in quantity and quality" (Dougherty, 2019, p. 21); 2) a first research step in which the team had to collect and analyze data and test the clarity of their first "theory of change"; 3) some activities aiming to determine the changes needed in the organization to improve its impact and develop a plan to get the support of the board, donors, staff, and other stakeholders; and 4) a last step aimed at engaging stakeholders and gaining support. The whole process, with a tight timeframe for each step, was supervised by the coaches, who commented on the work of the team every two weeks.

\section{Data collection and analysis}

This study's methodological approach is based on the in-depth case study of this consultant-led process using documents as its main source of data. The first author was the secretary of Enacting's board of directors. Through this experience, she actually took part in the "strategic clarification process" (also referred to by ConsultingCo as the "Clarity and Impact" module of training), together with other representatives from the Enacting employees and board. She thus got privileged access to five meetings, together with full access to all documents and additional exchanges between Enacting participants and ConsultingCo coaches. Early in the process, Enacting staff showed great interest in documenting the process and its impacts through research. Upon the completion of the ethics committee requirements from the first author's university_in which Enacting overtly acknowledged her role in the process—the other two researchers were also granted access to all of the material gathered. While careful reading and the initial coding of the data confirmed some of the first author's insights, other fresh observations emerged.

In addition to the first author's first-hand experience and written observations of the process as it unfolded, the central data set includes 45 documents produced over the six-month period of coaching. This corpus includes documents from both Consulting $\mathrm{Co}$ (mostly PowerPoint slides and other documents presenting and explaining the module and its tools) and Enacting. Multiple documents accessed from Enacting included written responses to ConsultingCo's requests (drafts of the theory of change, the reactions of actors involved, questions, etc.) throughout the process, many of which use the "Track Changes" mode in Microsoft Word. This made it possible to follow the reflections in greater detail and to capture some of the naturally occurring reactions to and iterations of the documents.

Following the first narrative strategy to analyze data (Langley, 1999), the story of the case was reconstituted in a chronological way. The actual coaching process, divided into the four steps previously described, facilitated the identification of six distinct phases that emerged from the temporal-bracketing strategy (Langley, 1999). The process and tools used to help Enacting to identify clearly, in ConsultingCo's terms, "where to focus the effort and how to measure the success," were analyzed, thus eliciting the different worlds (Boltanski \& Thévenot, 2006) being upheld. Each version of the organizational "theory of change" drafted along the process was scrutinized, with special attention paid to the actors staged, the characteristics attributed to them, the qualities granted, and the activity being appreciated, in order to identify and 
communicate the impacts deemed important by Enacting, and ConsultingCo's reactions to these propositions. Different versions were compared and used to evaluate activity and decisions made during the process in order to unpack the "worlds" deployed by ConsultingCo and the elements that facilitated the major changes between Enacting's initial, implicit theory of change - and thus of the initial definition of its stated purpose - and its theory of change at the final stage of the coaching module.

\section{FINDINGS}

Findings presented in this section follow ConsultingCo's coaching process, with special emphasis both on Enacting's theory of change over the six-month period and related reflections, and on ConsultingCo's actions (including the proposed tools and coaching approach) along the way. Following Kathleen Eisenhardt and Melissa Graebner (2007), the following narrative is "interspersed with quotations" and "intertwined with the theory to demonstrate the close connection between empirical evidence and emergent theory" (p. 29). Since the process is a highly structured step-by-step process, the narrative is also organized in phases to more closely illustrate the case and display the elements that supported the change in values that occurred along the way.

\section{Phase one}

Before it all started: Enacting's approach

In order to demonstrate the changes throughout the process, the findings start with a brief presentation of Enacting's approach prior to ConsultingCo's intervention. This starting point was actually expressed in a published chapter written by the general manager to document the organization's intervention approach developed through the years. This material is complemented by the first author's knowledge of Enacting. The approach is summarized in Figure 1.

Figure 1: Enacting's initial approach*

\begin{tabular}{|l|l|}
\hline \multicolumn{2}{|c|}{ Enacting's approach underpinnings } \\
\hline Philosophical & $\begin{array}{l}\text { People who live in oppressive situations or poorly resolved conflicts are the best positioned } \\
\text { to find solutions adapted to their own reality. }\end{array}$ \\
\hline Pedagogical & $\begin{array}{l}\text { Experiential communication makes people experience something that stimulates the senses, } \\
\text { evokes feelings, and generates the need to act. }\end{array}$ \\
\hline Artistic & $\begin{array}{l}\text { Emotion and imagination are critical anchors for the urge to act. Artistic and playful } \\
\text { experiences are facilitators to experience one's own humanity, to find a sense of life, and } \\
\text { enter into dialogue on this basis with others. }\end{array}$ \\
\hline
\end{tabular}

Note: *Based on the general manager in 2012. This reference is voluntarily concealed to hide the organization's identity. It refers to a book chapter authored by the general to present Enacting's approach in detail.

The general manager's reflections on Enacting's approach and vision also revealed how Enacting, prior to the intervention by Consulting $\mathrm{Co}$, justified its activities and what it valued. The target or actor of change and the subject was the citizen, and more specifically an oppressed citizen to be emancipated. This required the development of self-knowledge and selfconsciousness of experiential nature, rooted in pleasure, embodiment and heart (vs. ideas and discourses). This was to be facilitated by one's experience of participative theatre intervention. That was where Enacting entered the action.

The central stage actor, in line with the approach of the Theatre of the Oppressed, is the citizen, an oppressed person. Consequently, this actor's perspective can only change through empowerment, and solutions lie within the individual. 


\section{Mailhot, Michaud, \& Tello-Rozas (2020)}

Enacting was thus no expert; it was not the main actor nor the provider of emancipation tools. The citizen himself/herself already possessed those tools: one's own body, mind, experience. Enacting was only there to help the citizen discover and use his/her own resources; this happens through the experience of theatre and play, as the oppressed person accesses his/her personal power to act on situations and to change the way things are in society. Indeed, the artistic experience is to bring about the change for the oppressed citizen, and to inspire the will to act and join others. For Enacting, a deep, engaged experience of art was the key to empowered citizens who can use dialogue to mobilize within themselves and around them. In Boltanski and Thévenot's (2006) terms, prior to ConsultingCo's intervention, Enacting drew its evaluation criteria of subjects, tools, and actions that matter from the inspired and the civic worlds, with worth respectively grounded in inspiration and collective action (see Table 1). Then ConsultingCo and the Clarity and Impact module came into play.

\section{Phase two}

ConsultingCo's introduction of the clarity and impact module

In the summer of 2014, prior to the first meeting with the two ConsultingCo consultants, Enacting representatives were given homework, including reading an article about ConsultingCo's method (published in the Harvard Business Review) and watching a video outlining the approach. Ahead of the first encounter, ConsultingCo insisted that the Enacting team take note of the difficult reality of the NPO's environment: the NPO market is characterized by resource scarcity. From the outset, ConsultingCo introduced market world entities, such as competition and revenue, into the context of intervention.

In their first encounter with Enacting, consultants from ConsultingCo cast themselves in the domestic world as caring, supporting, and accompanying partners there to help Enacting survive in a difficult, competitive environment. The strategic clarification module is based on frequent discussions with the two consultants, who present themselves as "coaches," available for one-hour bi-weekly "support calls." This supportive "domestic" world mode of interacting is illustrated in the following quote (excerpted from ConsultingCo's presentation in its original, introductory slides): "We support nonprofits to help their leaders make difficult decisions daily."

The domestic, caring relationship is reinforced by ConsultingCo's early introduction of tools that are based on the industrial world, yet presented in a simple, straightforward, and accessible manner that makes them look easy and powerful. In essence, according to ConsultingCo, Enacting needed to determine its intended impacts and then work backward to deduce the actions and resources necessary to encourage them. The first set of information slides presented to Enacting offered a glimpse of the entire set of tools (i.e., an impact statement with impact measures, a theory of change, an action plan, and a plan for knowledge generation) that would be developed through the process, as shown in the following excerpt (again, from ConsultingCo's introductory slides): "At the end of the process, participants will have a clear statement of intended change and theory of change, and a plan of implementation."

ConsultingCo also mobilized the fame world by sharing success stories (using storytelling and testimonies from other nonprofits that benefited from ConsultingCo's support) and press (through reference, for instance, to the prestigious Harvard Business Review article). The following quote, also drawn from the same initial PowerPoint presentation, encapsulates this demonstration of the consultants' public recognition and legitimacy in the field:

To date, ConsultingCo has worked with nearly 200 organizations and more than one hundred partners in all regions of Canada by:

- providing funding;

- coaching and mentoring;
- workshops;

- module development. 


\section{Mailhot, Michaud, \& Tello-Rozas (2020)}

The following quote, the final one from ConsultingCo's initial presentation to Enacting, brings together elements of justification from the industrial, domestic, market, and fame worlds:

Practical tools for social innovation: How can ConsultingCo help you now!

Community organizations must be able to respond quickly to opportunities. Partnering with ConsultingCo helps

to prepare plans and develop better funding proposals. Specifically, ConsultingCo can help organizations:

- Quickly clarify current strategy and thoughtfully consider new initiatives that align with their plan to generate substantial outcomes.

- Learn about and inspire new high impact approaches that could be adopted.

The six-month process was facilitated by enthusiastic coaches and supported by various documents, including PowerPoint slides and a ten-page guide that presents the highlights of the "Clarity and Impact" module. Moreover, Enacting did the work, allowing leaders, through the dedicated team comprised of board members and staff, to follow the module, be involved in the reflections, and make decisions along the way.

In order to create its theory of change (i.e., to determine the activities to be developed to achieve the intended impacts), Enacting was invited to follow a structured step-by-step process. This process started with the search for relevant data (evidentiary data supporting claims of impacts, data about the environment, results, etc.) and then encompassed creating a visual representation of Enacting's theory of change. ConsultingCo's instructions were clear: this visual representation should include programs, activities, inputs, and targets in different boxes, with "lines to indicate cause-effect links between two elements (based on the organization's research or experience)."

\section{Phase three}

Enacting's first draft of its theory of change-and ConsultingCo's guidance and clarification

Following ConsultingCo's instructions, Enacting drafted a first version of its theory of change. To do so, Enacting instinctively began with what it is, what it does, and why (its purpose, philosophy, action, values). From there, the organization envisioned its impacts. This is clearly demonstrated in Enacting' intuitive ordering of the different columns it used to organize the first draft of its theory of change, as shown in Figure 2.

\section{Figure 2: Column headings in the first version of Enacting's theory of change}

\begin{tabular}{|l|l|l|l|l|}
\hline \multirow{2}{*}{ Our approach } & \multirow{2}{*}{ Who we engage with } & \multirow{2}{*}{ Our activities } & Short-term/direct & Medium- term/indirect \\
\cline { 4 - 5 } & & \multicolumn{3}{|c|}{ Results } \\
\hline
\end{tabular}

Given Enacting's specific approach, the organization first aimed to start from there to reflect, then to decline the intended results for which measurement tools were to be developed. Let us recall that for Enacting, the main actor is the oppressed citizen, to be empowered through a powerful theatrical experience.

ConsultingCo quickly reoriented Enacting's first draft of its theory of change. Indeed, ConsultingCo takes a completely opposite approach: Enacting is required to start by identifying its intended impact, then elaborating its theory of change into an action plan that considers all of the changes the organization must make in order to reach its intended impacts. In line with the higher principles of the industrial world that strongly underpin the theory of change, such as efficiency and performance, this perspective means that activities that do not lead to the specific intended impacts ought to be eliminated. While ConsultingCo's initial perception that a theory of change could have been about the "social change" to be brought about in society, it thus appears to be a theory of the (organizational) changes required by organizations to reach the im- 


\section{Mailhot, Michaud, \& Tello-Rozas (2020)}

pacts they claim to have on society. Nonetheless, Enacting agreed to play by ConsultingCo's rules and reversed the formulation of its theory of change, as is indicated by the organization of information in its second draft (see Figure 3).

\section{Figure 3: Column headings in the second version of Enacting's theory of change}

\begin{tabular}{|l|l|l|l|l|}
\hline What's the objective to reach? & For whom? & For when? & How? & Questions ... \\
\hline
\end{tabular}

As can be seen in Figure 3, however, Enacting added a column to allow for questions. Indeed, in developing their first theory of change, participants from Enacting made an explicit request that the process would help them clarify the political and civic dimensions of their interventions. In answer to the question, "What do you look forward to get from the process?" asked by consultants, Enacting members responded (in a separate document generated by Enacting):

- Clarify the political dimension of our intervention

- Promote collective adhesion (core and extended team) to achieve this dimension

- Clarification of the leadership and structure required to advance further

- How can Enacting become (100\% citizen!) more democratic and artistic (creative) in the inclusion of citizens in determining its priorities

- Identify the theoretical foundations of our change

- Identify the impacts and skills we want to see develop in our target

Through overt mentions of the political dimension of their intervention, together with their collective, democratic, and artistic/creative approach, Enacting participants clearly reiterated their hope that the process would allow the organization to engage its actions further within the civic and the inspired worlds of worth, with citizens themselves leading Enacting's definition of its purpose. Interestingly, while one of Enacting's motivations to engage in the process was the hope that the strategic clarification module could help the NPO gain further support, this expectation was not explicitly stated.

\section{Phase 4}

Another round of theory of change and ConsultingCo's comments

By November 2014, a more complete, written version of Enacting's theory of change was produced. As requested by ConsultingCo., it started with an impact statement. In this impact statement, Enacting presented itself as "a cultural nonprofit pursuing the mission to mobilize knowledge, solidarity and citizen power to create a more fair, equal world." This led one coach to comment (in the track changes function of the document): "You will thus want to measure how your activities have an impact on the mobilization of knowledge, solidarity and citizen power."

This version of the theory of change still contained a box describing Enacting's approach-in which the oppressed citizen finds his/her solution and still is the central agent of change. However, for the first time, Enacting aimed to identify its responsibilities in the process of change (create space, gather, mobilize, solicit, etc.). In doing so, the organization tried to clarify its role in social change. Was Enacting a trigger to make people think, become aware, or change their behaviour, letting them live a common artistic experience so that later they can act together? Was it a multiplier that supports collectives toward concrete actions-in collaboration with partners who have expertise in the field-mobilizing action and targeting the transformation of environments? In the different versions of the theory of change produced in this period, coaches queried these reflections with questions such as: "You are going to measure more specifically: the change of behavior, insights, and the number of collective actions performed by the groups following their work with you?" 


\section{Mailhot, Michaud, \& Tello-Rozas (2020)}

Reflecting on its role in bringing about social change inspired Enacting to finally depict its intervention along a "mobilization continuum" (see Figure 4).

Figure 4: The initial mobilization continuum

\begin{tabular}{|l|l|l|l|l|}
\hline \multicolumn{4}{|c|}{ Interventions in a mobilization continuum } \\
\hline Recognition & Experience-reflection & Change mobilization & Engagement partneringinnovation & Social harmony \\
\hline
\end{tabular}

For each column, considered as a step toward social harmony, Enacting members try to specify, as requested by the two coaches, results that can be measured (short-term/12 months, medium-term/three to five years, long-term). The coaches kept challenging Enacting with questions such as: "Can you identify something more precise to measure here?" Over many meetings, Enacting drew different versions of its theory of change and mobilization continuum (see Figure 5 for example).

Figure 5: The revised mobilization continuum

\begin{tabular}{|c|c|c|c|c|}
\hline Recognition & Gathering & Experimentation-reflection & Change / transformation & Social cohesion \\
\hline
\end{tabular}

The Enacting team also added the following questions and issues at the end of the document:

We have discussions and choices to make in our mobilization continuum, mainly we intervene at this point in the first three columns (recognition, gathering, and experimentation).

- Do we want to go to more toward change, transformation and sustainability?

- Do we want to take more leadership in the topics to explore, meet the social challenges in our own initiative?

- Would it mean to neglect specific "commands"?

- What filters are we going to give us to choose our projects?

The members of the Enacting team thus began to realize they could not be held responsible for social transformation. They started internalizing the coaches' questions and exploring how to choose their activities and projects based on this continuum, and how to measure the results of the activities identified in the first three columns. A great concern for measurement began to permeate the meetings and exchanges within the team. Notably, the acting general manager of Enacting, among others, began to take over the coaches' questions on measurement issues in her exchanges with the general manager (on sabbatical).

Discussions went on between the team members through different versions of the continuum. One line at the end of the table remains empty in several versions: the impact measures. Once the activities defining the different steps are precise enough, coaches suggest measures and propose that the arrow used to indicate Enacting's area of accountability stops at the activities for which the organization bears direct responsibility, finally pushing Enacting team members to write down some impact measures (see Figure 6). 
Mailhot, Michaud, \& Tello-Rozas (2020)

Figure 6: Another version of the mobilization continuum

\begin{tabular}{|c|c|c|c|c|c|}
\hline & Recognition & Gathering & Experimentation-reflection & Ttransformation & Social cohesion \\
\hline $\begin{array}{l}\text { Impact } \\
\text { measures }\end{array}$ & $\begin{array}{l}\text { Awareness } \\
\text { Identification of } \\
\text { discomfort } \\
\text { Expression of the } \\
\text { recognition of the lived } \\
\text { experience of others } \\
\text { New knowledge } \\
\text { acquisition } \\
\text { Development of new } \\
\text { skills }\end{array}$ & $\begin{array}{l}\text { Exchange or } \\
\text { relationship } \\
\text { developed with } \\
\text { someone living a } \\
\text { different realily than } \\
\text { me } \\
\text { Network expansion } \\
\text { Re-assessment of } \\
\text { (wrong) beliefs }\end{array}$ & $\begin{array}{l}\text { Change of perception } \\
\text { Change of behaviour } \\
\text { Identification of individual, } \\
\text { collective, and institutional } \\
\text { engagements } \\
\text { Better feeling of belonging }\end{array}$ & $\begin{array}{l}\text { Change in practices } \\
\text { Pilot projects } \\
\text { Innovative actions } \\
\text { Mediatic actions } \\
\text { New, further training } \\
\text { followed by } \\
\text { participants } \\
\text { New research } \\
\text { projects }\end{array}$ & \\
\hline
\end{tabular}

The questions raised throughout the six-month process of drafting the different versions of the theory of change were compiled into a document. Introductions were added to account for elements the Enacting team members were unable to incorporate into the continuum. The general manager wrote a preamble that is partly included in the introduction to the theory of change.

In this preamble, the general manager relies on the inspired and civic worlds to try define the purpose of the organization: make "playful politics," "fight in the fun." For him, Enacting is doing and must keep doing social transformation (not in the long term, not even in the short term, but in the "here and now," as he expresses it). An excerpt of the preamble reiterates the general manager of Enacting's deep attachment to the initial approach:

Enacting assumes that the expertise of citizens of all ages, men and women, to improve the condition of their community, is well worth that of the specialists and community intervenors.

Daily, Enacting creates, with its partners and its public, places of dynamic exchanges where the reality of people is shown; the experiential, intervention, scientific and sometimes management knowledges are exposed, defended and discussed. Through these discussions, we build communities that are latent. We rebuild links between communities' actors, we help reshape the relationships between them. New forms of solidarity emerge, and we encourage our audience to commit to sustainable actions of transformation of our environments.

Our participative formula, with the results that are lived in the moment, in the immediacy of public trials for transforming human relationships, reverse or at least alter relations of power and domination. This immediacy revolutions how we think of the dominant and the dominated. With Enacting, another world is possible, in pleasure, in conviviality, in mostly friendly confrontations, and the change is not in the distant future but in the here and now!

\section{Phase five}

Putting the theory of change to the test: ConsultingCo's sceptical intervention

Once Enacting developed an impact statement and theory of change, ConsultingCo put on a new hat. While its initial relationship with Enacting had been mostly cast in the caring, domestic world, the industrial world takes over this stage in two steps. First, Enacting's theory of change is literally put to the test in January 2015, and this test is conducted within the industrial world. ConsultingCo gave another PowerPoint presentation, this one entitled, "Evaluation of your Theory of Change 


\section{Mailhot, Michaud, \& Tello-Rozas (2020)}

Under Pressure." In this presentation, ConsultingCo introduces three fictitious characters, "sceptical people" who ask three questions to test the strength of Enacting's theory of change:

1. Really? (program analysis)

2. Can you prove it? (analysis of external data)

3. Why you? (analysis of the ecosystem)

Sceptical people raised many other questions later in the PowerPoint presentation. The coaches invited Enacting participants to identify which ones to address first. The next step was for Enacting to develop the tools to answer these questions. This took the form of an Excel spreadsheet aimed at documenting the impacts of theatrical interventions, and at setting objectives, percentages, budgets.

In March 2015, ConsultingCo gave Enacting another presentation. This one was on five common pitfalls of developing a theory of change:

Creating a Theory of change is less easy than what we think. Look at your document and try to avoid the following common pitfalls:

1. Lack of clarity on the links between programs ...

2. Creating a mirror instead of a target ...

3. Lacking precision, which prevents us from measuring ...

4. Confounding evidence and plausibility ...

5. Not being true to your theory ...

Two important observations must be formulated here. First, in the initial presentation, the ConsultingCo coaches did not directly challenge the Enacting team members; they challenged them indirectly through the three sceptical actors. Two months later, however, there was a change in the relationship: ConsultingCo's coaches no longer used the sceptical actors to challenge Enacting. Once the first step of moving from the domestic relationship to the industrial-proof worlds was taken (thanks to the scepticals' personification in the January presentation), coaches could be more straightforward in the way they questioned Enacting's theory of change.

After these presentations, Enacting produced two versions of its theory of change (at the beginning and the end of April 2015). Along the way, coaches kept asking for more arrows and causal directions, for links to be clarified, and for an action plan with ranked priorities. At this point, the theory of change clearly led to the implementation of changes in the organization in order to reach the intended impacts. That being said, remarkably, at the same time, emotions and empathy were (re)introduced in the "zone of imputability" of the theory of change. We cannot claim that the strong pressure to jump into the industrial world in this phase caused Enacting to go back to the roots of its implicit inspired/civic worlds' "natural" foundation (which had somewhat been neglected along the process). That being said, we can note that up to then, the mode of expressing judgement or proofs of these worlds had not been integrated into the process and tools developed. In short, ConsultingCo's approach, mainly based on the industrial world's common superior principle of the "common good" of efficiency and performance-which experts promote with specific structured tools and methods - challenged Enacting's own approach to the common good, which was based on very distinct considerations of what is of value. 


\section{Phase six}

Enacting's theory of change: The end result

Enacting's final theory of change document does not promote citizen emancipation through self-knowledge or experiential knowledge; it does not speak to the idea of using experience to create emotion that then generates an urge for action. Enacting still struggles to see what it is to be responsible for. Following what is of value in the industrial world, its interventions of transformation have been encrypted, with quantified targets, as requested by ConsultingCo coaches. When compared with Enacting's initial approach (see Figure 1), in which the central character and "expert" is the citizen who is empowered through theatre experience, in this approach, Enacting is centre stage in a mobilization project (see Figure 7).

Figure 7: The final version of Enacting's theory of change

\begin{tabular}{|c|c|c|c|c|}
\hline $\operatorname{Recc}$ & & & & $?$ \\
\hline $\begin{array}{l}\text { Hear the voices of } \\
\text { people seeking } \\
\text { affirmation in public } \\
\text { space; } \\
\text { See and recognize } \\
\text { the realities of } \\
\text { individuals and their } \\
\text { concerns } \\
\text { The intervention of } \\
\text { Enacting makes it } \\
\text { possible to: } \\
\text { Put oneself in } \\
\text { someone else's } \\
\text { place. } \\
\text { Identify and query } \\
\text { power relations, } \\
\text { governing conditions, } \\
\text { and situations. } \\
\text { Recognize } \\
\text { reciprocity. }\end{array}$ & $\begin{array}{l}\text { problems, and } \\
\text { inequities } \\
\text { Lift people out of } \\
\text { isolation } \\
\text { The intervention } \\
\text { of Enacting } \\
\text { makes it } \\
\text { possible to: } \\
\text { Gather people } \\
\text { and groups } \\
\text { around collective } \\
\text { projects. } \\
\text { Encourage } \\
\text { dialogue between } \\
\text { actors to mobilize } \\
\text { for solutions. }\end{array}$ & $\begin{array}{l}\text { Experiment and test } \\
\text { potential solutions by } \\
\text { interactive play and } \\
\text { theatrical situations. } \\
\text { Identify and live the } \\
\text { desired change. } \\
\text { The interactive } \\
\text { theatre of Enacting: } \\
\text { Causes changes in } \\
\text { perceptions and } \\
\text { behaviours among } \\
\text { participants. } \\
\text { Clarifies the vision of } \\
\text { the desired transformed } \\
\text { reality. } \\
\text { Induces individual and } \\
\text { collective commitments } \\
\text { to improve the } \\
\text { environment or living } \\
\text { conditions. }\end{array}$ & $\begin{array}{l}50 \text { externally (+50\%) multipliers. } \\
\text { Support, develop, and encourage } \\
\text { changes in practice toward } \\
\text { participatory methods promoting a } \\
\text { continuum of mobilization. } \\
\text { The transformation advocated by } \\
\text { Enacting means: } \\
\text { The co-creation of } 10 \text { (+50\%) and } \\
\text { multiplying initiatives actions } \\
10 \text { (+100\%) citizens proposed } \\
\text { legislation, regulations, codes of } \\
\text { ethics adapted, innovative } \\
\text { Mobilizing more than } 1,000 \text { (+30\%) } \\
\text { citizens continuously (six months } \\
\text { and longer) and sustainably (over } \\
\text { five years). } \\
\text { The co-development of new } \\
\text { knowledge andpartnerships } \\
\text { throughour Communities } \\
\text { Practice leaders (ICC CPL). }\end{array}$ & $\begin{array}{l}\text { Transfer the intervention } \\
\text { methods to act on the systems } \\
\text { and territories in aviable and } \\
\text { sustainable way. } \\
\text { The contribution of Enacting } \\
\text { to achieving this global } \\
\text { solidarity is: } \\
\text { Creating strategic alliances } \\
\text { with our PUBLIC } \\
\text { (research,spokespersons, key } \\
\text { players, the political network } \\
\text { of organizations, etc.) to: } \\
\text { Claim, defend, and adopt } \\
\text { transformations in policies } \\
\text { and management practices. } \\
\text { Ensure better policy } \\
\text { enforcement of existing } \\
\text { regulations and legislation. } \\
\text { Link local struggles to } \\
\text { national and international } \\
\text { ones. } \\
\text { Co-celebrate achievements. }\end{array}$ \\
\hline
\end{tabular}

At the end of the process, the NPO's legitimacy lies on its ability to bring people together and foster dialogue. It is thus the organization that now holds expertise. Enacting's explicit role of doing good is no longer to bring about an existential change to individuals but rather to get people together and, through a series of steps, make people understand each other and find solutions together. An important transformation of how the NPO envisions its purpose (and a transformation of its conception of the common good) has thus occurred, based on Enacting's internalization of ConsultingCo's concern with measure. Indeed, it is easier for Enacting to demonstrate its capacity to bring people together (counting them, cataloguing the actions they launched, etc.) than it is to dig into the individual, personal experience of an enlightened, emancipated citizen whose life was moved by an inspiring theatre intervention. Figure 7 illustrates the end result of Enacting's theory of change.

\section{DISCUSSION AND CONCLUSION}

While scholars interested in NPO's evaluation and impacts have extensively documented the different motives, typologies, approaches, and logics used to assess the activities and results of those organizations (e.g., Dougherty, 2019; Eckerd \& 


\section{Mailhot, Michaud, \& Tello-Rozas (2020)}

Moulton, 2011; Grieco et al., 2015; Hall, 2014), this article started by observing that little (if any) of that research had taken a "valuation" lens to explore the process by which organizations determine what is being valued, nor how this may change. Thus, the processes through which value is ascribed in the setting up of some tools and indicators must be unpacked. As the very action of evaluating points to the attribution of value, it is important to not only question what was valued but also, more fundamentally, how the process of setting up impact assessment tools may actually change the way NPOs envision their purpose and legitimize their actions. The Economies of Worth framework (Boltanski \& Thévenot, 2006) represents a relevant and rich analytical grid through which this could be examined.

The following section recounts the interactions between the different worlds of the Economies of Worth framework along with the process of valuation an NPO undergoes through the development of its theory of change. Three elements by which the introduction of evaluation tools brings about changes in the NPO's theory of change are introduced, namely the principles on which the relationship with the consultants was established, the deductive approach adopted by them, and, finally, the set of tools used to frame the process and collect the data. Insights that the current research adds to the existing relevant literature with regards to NPO's impact assessment and valuation are introduced, along with practical implications and considerations for NPOs.

\section{Process of evaluation through French pragmatist sociology's Economies of Worth (EW)}

The Enacting case study displays how the introduction of impact assessment measurement tools can instill NPOs with legitimization principles based in the industrial world. This ultimately may lead NPOs to favour activities that can be valued through the tools of that world_activities with measurable impact. Despite the domestic (supportive, caring) veneer applied to the consultant-NPO relationship at the beginning of the process studied here, the module is directed toward the implementation of tools aimed at increasing performance and efficiency. Asking for precise, measurable proof inevitably leads to particular principles of legitimation: those of the industrial world.

The analysis of this case also serves to illustrate how different worlds can be mobilized during an evaluation process. Each phase of the coaching process described above was characterized by the predominance of some worlds. In the first phase, prior to the consultants' intervention, the actions of the NPO were guided by the inspired and civic worlds, and it mobilized tools based mainly on individual creativity. During the second phase, consultants began to introduce industrial tools using justifications and related actions from the market, domestic, and fame worlds: the scarcity of available resources was highlighted (market), the supportive "coaching" relationship was emphasized (domestic), and successful cases of organizations that have been legitimized through a solid theory of change and mentions of media coverage (fame) were presented. The incursion of the industrial world became clearer in the third phase of the intervention through measures and evaluation indicators. Phases four and five constituted a kind of breaking point in relation to the initial vision of the NPO's purpose. Indeed, during the fourth phase, elements characterizing the industrial world began to appear in some tools produced by the NPO (see, for instance, the "initial mobilization continuum" in Figure 4); in the fifth phase, elements of this world also became explicit in the consultants' discourse. As a result, the NPO's planned actions came to be evaluated and measured in the short, medium, and long terms. This pervading of the industrial world became even more evident in the sixth phase: the need to use performance tools to measure and quantify was made explicit in the final version of the NPO's theory of change. Over this process, the central actor of transformation also changed radically. While during the first phases, the "excluded citizen" is the actor around whom Enacting is "doing good," in the last phase, the organization itself becomes the main agent of social change.

\section{(E)valuation tools that may transform NPOs' purpose}

While the literature on impact measurement has emphasized the potential conflicts regarding the logics of evaluation (Hall, 2014), this study depicts a rather smooth process. Despite the transformation of an initially inspired and civic conception 


\section{Mailhot, Michaud, \& Tello-Rozas (2020)}

of Enacting's purpose, through the contact of the industrial world, we observed no open quarrel. This could be partly explained by the fact that the NPO was struggling in a critical financial context of scarcity, and that it lacked long-term strategic planning. Such context may have made Enacting more open to advice that could bring in new resources. This, together with ConsultingCo's confident turnkey approach and demonstrable results, may explain the NPO's relatively smooth acceptance of the consultants' tools and made it possible to transform the concept of the purpose on which the organization based its legitimacy without generating heated philosophical debates. The intervention process was not based on shared superior principles among stakeholders (what subjects, objects, actions are valued by the organization). Instead, the point of departure of the process was the ability to measure impact. Unlike most of the studies using the EW framework, this organization was never engaged in a controversial process or dispute over legitimacy that would have required the NPO to justify itself on the basis of higher principles of what is considered as common good (Patriotta et al., 2011).

As a result, in order to be valuable, Enacting's activities and purpose needed to be measured with proven results. Consequently, Enacting had to substantially review its theory of change: to legitimate itself, the organization needed to reconsider its role to be able to capture (quantitatively, objectively) the impacts of its action and to make sure that the resulting effects could positively be evaluated. This is in line with Wanda Orlikowski and Suzan Scott's (2014) observations that valuation works "by standardizing, simplifying, and quantifying assessment information, that they are based on the expertise of a small number of legitimized authorities, that they favor incumbent and high-status participants, and that they trigger organizations to change reactively and predictably in conformance with explicit valuation criteria" (p. 868).

This study makes at least three important contributions. First, the analysis offers a way out of the usual, dualistic contrasts between economic and social evaluations (Kornberger, 2017; Stark, 2011) and it opens the discussion about impact measures for NPOs by finally considering the more numerous evaluation metrics associated with multiple worlds that are implied in the process of developing impact measurement tools. Through Boltanski and Thévenot's (2006) Economy of Worth framework, used here as an analytical grid, this case makes it possible to note that the "social" may relate to civic but also to inspired and even domestic worlds, and that the "economic" may resonate with market and industrial worlds. That being said, the consultants' approach is built exclusively on industrial tests, making it impossible to present evidence from other worlds or to search for compromises (between industrial, inspired, or civic world, for instance). The same can be observed for the theory of change finally produced by the NPO, which seeks to homogenize its visions and projects: while the central idea of the NPO's initial approach was that each person connects to her/his own emotions and experiential knowledge to discover her/his own solutions, the main idea of the final version is that Enacting organizes exchanges during which people can better understand each other. This contrasts sharply with the idea that "dissonance" enables innovation (Stark, 2009), as well as with the idea of maintaining "coexistence of multiple matrixes of evaluation" (Lamont, $2012: 9$ ) as the only way to reduce inequities and injustices.

Second, this analysis also brings out the importance of tools, tests, and proof in the promotion of a certain "common good." Many scholars have analyzed management tools (Chiapello \& Gilbert, 2013), however, few of them have fully exploited Boltanski and Thévenot's Economies of Worth framework (2006) to reveal the different conceptions of the common good or fundamental purpose carried by objects and devices. This article invites reflection on the legitimacy of modes of judgement, and on the fact that worlds other than industrial are not easily captured through the more classical social impact measurement evaluation tools and models, such as the logical framework and social return on investment (Hall, 2014). As scholars, but also as practitioners and consultants in/for NPOs, it is necessary to think about what models, methods, or tools can be constructed and used to allow for different conceptions of what is of value. This ultimately raises the question of the extent to which industrial tools can capture inspired or civic worth. These questions become even

more important when considering the tools' effects on the organization, as the theory embedded in tools may differ from the logics that drive the organization's activities. As illustrated by the Enacting case study, the use of impact definition 


\section{Mailhot, Michaud, \& Tello-Rozas (2020)}

and measurement tools guide the construction of an organization's theory of change that may transform conception of its very purpose. Thus, these findings offer a contribution to the debate about the effects of social impact measures: they highlight the nature of the theory behind these measures and their possible effects on organizations' principles.

A third contribution is linked to the literature on valuation and evaluation. This study examined a type of organization, an $\mathrm{NPO}$, that is increasingly the subject of evaluation processes. More specifically, it examined an evaluation approach mobilized by consultants specializing in the social innovation field that urges organizations to look at the effects or consequences of economic evaluations of and on social and cultural activities research (e.g., Chiapello, 2015). At the end of the process studied here, Enacting seems to be like any other NPO whose main activity is to bring people together and promote conversation. While this can still be considered valuable, the NPO lost its specificity during the evaluation process - at least according to the documents they have produced (note the disappearance of intervention by means of art, theatre to touch the imagination and the emotions, to provoke changes in the symbolic, the body, etc.) -and became similar to many other "competing" NPOs struggling for funding. Based on its theory of change, Enacting has apparently eclipsed the special characteristics and purpose that allowed it to present itself as promotor and guardian of a certain common, better good in society.

Alternative approaches, such as the Economies of Worth framework, should be employed to understand the multiple ways NPOs can justify and legitimize their actions and the value they grant to their activities. This study draws attention to principles of worth objectified in methods and measurement tools, with their embedded conceptions of what is considered "good" and valuable. Of course, a single case study does not aim nor allow for generalization. This research argues, cautiously, for the theoretical "transferability" of our results for analyzing other experiences. There is room for research that further develops the ideas put forward here and aims to answer the question of how and which specific conceptions of the common good NPOs promote in the context of justifying their activities with funders and other stakeholders. Lastly, fellow nonprofit scholars and practitioners are invited to challenge their management view of measurement tools as axiologically neutral. The idea behind the management and impact assessment tools is to improve the efficiency and rationality of organizations in an industrial logic, in order to justify the existence of NPOs with their funders and justify the use of resources from stakeholders. Yet these tools embed principles that guide what is valued in terms of actions, subjects, and objects, which could transform nonprofit organizations in unexpected ways that need to be further investigated. This research thus opens some avenues for reflection on how NPOs define what is valued in each of the facets that make up the organization's management, from strategic planning to the eventual decision to evaluate their actions and activities.

\section{NOTES}

1. For a more detailed review of the EW framework, see for instance, Cloutier, Gond, \& Leca (2017); Cloutier \& Langley (2013); or Jagd (2011).

2. Here and henceforth, when empirical material is reported, the use of expressions in brackets without authorship precision refers to documents and material produced by ConsultingCo consultants/coaches.

\section{REFERENCES}

Alberio, Marco, \& Tremblay, Diane-Gabrielle. (2014). De la vision à l'action: la performance dans les entreprises d'insertion du Québec. ANSERJ, 5(4), 21-40.

Annisette, Marcia, Vesty, Gillain, \& Amslem, Thierry. (2017). Accounting values, controversies, and compromises in tests of worth. In C. Cloutier, J.P. Gond, \& B. Leca (Eds.), Justification, evaluation and critique in the study of organizations: Contributions from French pragmatist sociology (pp. 209-239), Bingley, UK: Emerald Publishing Limited. 


\section{Mailhot, Michaud, \& Tello-Rozas (2020)}

Arvidson, Malin. (2009). Impact and evaluation in the UK third sector: Reviewing literature and exploring ideas [Working paper 27]. Birmingham, UK: Third Sector Research Centre.

Arvidson, Malin, \& Lyon, Fergus. (2014). Social impact neasurement and non-profit organisations: Compliance, resistance, and promotion. Voluntas, 25(4), 869-886.

Barman, Emily. (2015). Of Principle and Principal : Value Plurality in the Market of Impact Investing. Valuation Studies, 3(1), 9-44.

Bertilsson, Jon, \& Rennstam, Jens. (2018). The destructive side of branding: A heuristic model for analyzing the value of branding practice. Organization, 25(2), 260-281.

Boal, Augusto. (1993). Theater of the Oppressed. New York, NY: Theatre Communications Group.

Boltanski, Luc, \& Thévenot, Laurent. (2006). On justification: Economies of worth. Princeton, NJ: Princeton University Press. Originally published [1991] De la justification. Les économies de grandeur. Paris, FR : Éditions Gallimard.

Chenhall, Robert H., Hall, Matthew, \& Smith, David (2013). Performance measurement, modes of evaluation and the development of compromising accounts. Accounting, Organizations and Society, 38(4), 268-287.

Chiapello, Eve. (2015). Financialisation of valuation. Human Studies, 38, 13-35.

Chiapello, Eve, \& Gilbert, Patrick (2013). Sociologie des outils de gestion. Introduction à l'analyse sociale de l'instrumentation de gestion. Paris, FR: La Découverte.

Cloutier, Charlotte, Gond, Jean-Pascal, \& Leca, Bernard (2017). Justifications, evaluation and critique in the study of organizations: An introduction to the volume. In C. Cloutier, J.P. Gond, \& B. Leca (Eds.), Justification, evaluation and critique in the study of organizations: Contributions from French pragmatist sociology (pp. 3-29), Bingley, UK: Emerald Publishing Limited.

De Munck, Jean, \& Zimmermann, Bénédicte. (2014). Evaluation as practical judgment. Human Studies, 38(1), 113-135.

Dewey, John. (1939). Theory of valuation. International Encyclopedia of Unified Science, 2(4), vii, 67.

Doganova, Liliana, Giraudeau, Martin, Helgesson, Claes-Fredrik, Kjellberg, Hans, Lee, Francis, Mallard, Alexandre, Mennicken, Andrea, Muniesa, Fabian, Sjögren, Ebba, \& Zuiderent-Jerak, Teun. (2014). Valuation studies and the critique of valuation. Valuation Studies, 2(2), 87-96.

Dougherty, Christopher Nicholas. (2019). Trust and transparency: Accreditation and impact reporting by Canadian charities. ANSERJ, 10(1), 6-25.

Eckerd, Adam, \& Moulton, Stephanie. (2011). Heterogeneous roles and heterogeneous practices: Understanding the adoption and uses of nonprofit performance evaluations. American Journal of Evaluation, 32(1), 98-117.

Eisenhardt, Kathleen. M., \& Graebner, Melissa E. (2007). Theory building from cases: Opportunities and challenges. Academy of Management Journal, 50(1), 25-32.

Espeland, Wendy Nelson, \& Sauder, Michael. (2007). Rankings and reactivity: How public measures recreate social worlds. American Journal of Sociology, 113(1), 1-40.

Eynaud, Philippe, \& Mourey, Damien. (2012). Professionnalisation et identité des associations du secteur social: chronique d'une mort annoncée? Politiques et management public, 29(4), 671-693.

Forbes, Daniel. (1998). Measuring the unmeasurable: Empirical studies of nonprofit organization effectiveness from 1977 to 1997. Nonprofit and Voluntary Sector Quarterly, 27(2), 183-202.

Fourcade, Marion. (2011). Cents and sensibility: Economic valuation and the nature of "nature." American Journal of Sociology, 116(6), 1721-1777.

Glassman, David M., \& Spahn, Kathy (2012). Performance measurement for nonprofits. Journal of Applied Corporate Finance, 24(2), 72-77.

Greiling, Dorothea, \& Stötzer, Sandra (2015). Performance accountability as a driver for changes in nonprofitgovernment relationships: An empirical insight from Austria. Voluntas, 26(5), 1690-1717.

Greatbanks, Richard, Elkin, Graham, \& Manville, Graham. (2010). The use and efficacy of anecdotal performance reporting in the third sector. International Journal of Productivity and Performance Management, 59(6), 571-585. 


\section{Mailhot, Michaud, \& Tello-Rozas (2020)}

Grieco, Cecilia, Michelini, Laura, \& lasevoli, Gennaro. (2015). Measuring value creation in social enterprises: A cluster analysis of social impact assessment models. Nonprofit and Voluntary Sector Quarterly, 44(6), 1173-1193.

Hall, Matthew. (2014). Evaluation logics in the third sector. Voluntas, 25(2), 307-336.

Heuts, Frank, \& Mol, Annemarie. (2013). What is a good tomato? A case of valuing in practice. Valuation Studies, 1(2), 125-146.

Jagd, Søren. (2011). Pragmatic sociology and competing orders of worth in organizations. European Journal of Social Theory, 14(3), 343-359.

Jäger, Urs P. \& Schröer, Andreas. (2014). Integrated organizational identity: A definition of hybrid organizations and a research agenda. VOLUNTAS: International Journal of Voluntary and Nonprofit Organizations, 25(5), 1281-1306.

Jarzabkowski, Paula, \& Kaplan, Sarah (2015). Strategy tools-in-use: A framework for understanding "technologies of rationality" in practice. Strategic Management Journal, 36(4), 537-558.

Kornberger, Martin. (2017). The values of strategy: Valuation practices, rivalry and strategic agency. Organization Studies, 38(12), 1753-1773.

Lamont, Michèle. (2012). Toward a comparative sociology of valuation and evaluation. Annual Review of Sociology, 38(1), 201-221.

Langley, Ann. (1999). Strategies for theorizing from process data. Academy of Management Review, 24(4), 691-710.

Lecy, Jesse D., Schmitz, Hans Peter, \& Swedlund, Haley (2012). Non-governmental and not-for-profit organizational effectiveness: A modern synthesis. Voluntas, 23, 434-457.

Lum, Janet M, Shields, John, \& Evans, Bryan. (2016). Co-constructing performance indicators in home and community care: Assessing the role of NGOs in three Canadian provinces, ANSERJ, 7(1), 46-73.

Luke, Belinda G., Barraket, Jo, \& Eversole, Robyn. (2013). Measurement as legitimacy versus legitimacy of measures: Performance evaluation of social enterprise. Qualitative Research in Accounting \& Management, 10(3/4), 234-258.

Mailhot, Chantale, \& Langley, Ann (2017). Commercializing academic knowledge in a business school: Orders of worth and value assemblages. In C. Cloutier, J.P. Gond, \& B. Leca (Eds.), Justification, evaluation and critique in the study of organizations: Contributions from French pragmatist sociology (pp. 241-269), Bingley, UK: Emerald Publishing Limited.

Martinus Hauge, Amalie. (2016). The organizational valuation of valuation devices. Putting lean whiteboard management to work in a hospital department. Valuation Studies, 4(2), 125-151.

Maier, Florentine, Schober, Christian, Simsa, Ruth, \& Millner, Rainhard. (2015). SROI as a method for evaluation research: Understanding merits and limitations. Voluntas, 26(5), 1805-1830.

Manetti, Giacomo. (2014). The role of blended value accounting in the evaluation of socio-economic impact of social enterprises. Voluntas, 25(2), 443-464.

Micheli, Pietro, \& Kennerley, Mike. (2005). Performance measurement frameworks in public and non-profit sectors. Production Planning \& Control, 16(2), 125-134.

Millar, Ross, \& Hall, Kelly (2013). Social return on investment (SROI) and performance measurement: The opportunities and barriers for social enterprises in health and social care. Public Management Review, 15(6), 923-941.

Moxham, Claire. (2010). Help or hindrance? Examining the role of performance measurement in UK nonprofit organisations. Public Performance \& Management Review, 33(3), 342-354.

Orlikowski, Wanda, \& Scott, Suzan V. (2014). Exploring apparatuses of valuation in the travel sector. Organization Science, 25(3), 868-891.

Patriotta, Gerardo, Gond, Jean-Pascal, \& Schultz, Friederike. (2011). Maintaining legitimacy: Controversies, orders of worth, and public justifications. Journal of Management Studies, 48(8), 1804-1836.

Reinecke, Juliane. (2010). Beyond a subjective theory of value and toward a 'fair price': An organizational perspective on fairtrade minimum price setting. Organization, 17(5), 563-581. 


\section{Mailhot, Michaud, \& Tello-Rozas (2020)}

Ruebottom, Trish. (2011). Counting social change: Outcome measures for social enterprise. Social Enterprise Journal, $7(2), 173-182$.

Stark, David. (2009). The sense of dissonance: Accounts of worth in economic life. Princeton, NJ: Princeton University Press.

Stark, David. (2011). What's valuable? In P. Aspers \& J. Beckert (Eds.), The worth of goods: Valuation and pricing in the economy. Oxford, UK: Oxford University Press.

Yu, Stan, \& McLaughlin, Darrell Arthur. (2013). Program evaluation and impact assessment in international nongovernmental organizations (INGOs): Exploring roles, benefits, and challenges. ANSERJ, 4(2), 23-36.

\section{ABOUT THE AUTHORS / LES AUTEURS}

Chantale Mailhot is Professor at HEC Montréal. Her current research focuses on practices of social transformation, on processes of co-production of research and on mechanisms of citizen engagement in decision-making. Email: chantale.mailhot@hec.ca

Valérie Michaud is Professor at ESG UQAM. Her research focuses on the paradoxes of managing alternative and social economy organizations. Email: michaud.valerie@uqam.ca

Sonia Tello-Rozas is Associate Professor at ESG-UQAM. Her current research focuses mainly on social and solidarity economy; social innovation and social inclusion methodologies promoted by nonprofit organizations. Email: tello -rozas.sonia@uqam.ca 